\title{
Chemical Taxonomy Applications of Some Water Mite Species (Acari, Hydrachnidia) Using Fourier Transform Infrared Spectroscopy (FTIR) Methods
}

\section{Fourier Dönüşümü Kızılötesi Spektroskopisi (FTIR) Yöntemlerini Kullanarak Bazı Su Akar Türlerinin (Acari, Hydrachnidia) Kimyasal Taksonomisi Uygulamaları}

\author{
Ferruh Aşçı $^{1}$, Gülderen Uysal Akkuş² ${ }^{2}$, Nazife Alpaslan ${ }^{1}$, Gamze Kübra Çetin ${ }^{1}$ \\ ${ }^{1}$ Department of Molecular Biology and Genetics, Afyon Kocatepe University, Afyonkarahisar, Turkey. \\ ${ }^{2}$ Department of Chemistry, Afyon Kocatepe University, Afyonkarahisar, Turkey.
}

\section{ABSTRACT}

Th his study employed water mite (Acari, Hydrachnidia) species collected from a natural lake water environment. These species included Hydrodroma despiciens, Eylais infundibulifera, Hydryphantes flexiosus, Georgella helvatica, Hygrobates nigromacutlatus, Hydryphantes thoni ve Torrenticola bevirostris. Chemical analyses of these species were conducted using the Fourier infrared spectrophotometer (FTIR) technique. Solid phase IR spectra were made individually for each species. The data obtained for all species were examined graphically and were identified in four different spectral regions. Finally, the spectrum frequency ranges of these species were determined. The functional groups $\mathrm{OH}, \mathrm{C}-\mathrm{H}, \mathrm{C}=\mathrm{O}, \mathrm{C}-\mathrm{O}$, and $\mathrm{C}-\mathrm{N}$ were observed. The vibrational frequencies of each species studied were determined. When evaluating the results of the spectroscopic analysis, the range of the spectrum of these species was shown to be similar to one another; however, peak intervals were different for each species.

\section{Key Words}

Water mites, acari, Hydrachnidia, infrared spectroscopy, chemical taxonomy.

öz

u çalışmada, doğal göl suyu ortamından toplanan su kenesi (Acari, Hydrachnidia) türleri kullanılmıştır. Bu türler Hydrodroma despiciens, Eylais infundibulifera, Hydryphantes flexiosus, Georgella helvatica, Hygrobates nigromacutlatus, Hydryphantes thoni ve Torrenticola bevirostris'dir. Bu türlerin kimyasal analizleri, Fourier kızılötesi spektrofotometre (FTIR) tekniği kullanılarak yapıldı. Katı faz IR spektrumları her tür için ayrı ayrı yapıldı. Tüm türler için elde edilen veriler grafiksel olarak incelendi ve dört farklı spektral bölgede tanımlandı. Son olarak, bu türlerin spektrum frekans aralıkları belirlendi. Fonksiyonel gruplar $\mathrm{OH}, \mathrm{C}=\mathrm{H}, \mathrm{C}=\mathrm{O}, \mathrm{C}=0$ ve $\mathrm{C}=\mathrm{N}$ gözlendi. Çalışılan her türün titreşim frekansları belirlendi. Spektroskopik analiz sonuçları değerlendirilirken, bu türlerin spektrum aralığının birbirine benzer olduğu ancak, en yüksek aralıkların her tür için farklı olduğu gösterilmiştir.

\section{Anahtar Kelimeler}

Su keneleri, acari, Hydrachnidia, infraraed spektroskopi, kimyasal taksonomi 


\section{INTRODUCTION}

A large number of studies have been conducted on - water mites that are commonly found in marine and inland waters. Water mite species (Acari: Hydrachnidia) belong to 57 families, 400 genera and approximately 6000 species [1-6]. Water mites are important ecologically as bioindicator organisms. Molecular and chemical studies have been conducted on this group [7- 14]. In terms of solving systemic problems and the level of understanding of the phylogenetic relationships encountered between water mites, chemical techniques have recently been employed $[7,8,10,11]$. The data obtained by this method serve as a significant contribution for systematizers and taxonomists. Considering the continuing systematic discussion of some water mite species, it is important to note that the molecular and chemical methods currently being employed by researchers indicate certain and clear results.

The FTIR technique used in this study provides determination of functional groups' $(\mathrm{OH}, \mathrm{C}-\mathrm{H}, \mathrm{C}=\mathrm{O}, \mathrm{C}-\mathrm{O}, \mathrm{C}-\mathrm{N}$, etc.) structure by measuring the vibrational energy of molecules within the structure. This method is generally used to determine the structure of chemical compounds, particularly organic compounds, alongside other spectrophotometric methods (NMR, Mass, UV, etc.) [15-16].

Infrared spectroscopy is a spectroscopy-based technique that absorbs the infrared rays of the material under study. All molecules, except for homo-nuclear $\left(\mathrm{N}_{2}, \mathrm{O}_{2}, \mathrm{Cl}_{2}\right)$ molecules, have a unique infrared spectrum. The IR spectrum is generally divided into four regions: $3700-2700 \mathrm{~cm}^{-1}(\mathrm{X}$ H); $2700-1850 \mathrm{~cm}^{-1}$ (triple bonds); $1950-1550 \mathrm{~cm}^{-1}$ (double bonds) and $1550-600 \mathrm{~cm}^{-1}$ (except for $\mathrm{X}-\mathrm{H}$, single bonds).

- The $3700-2700 \mathrm{~cm}^{-1}$ region: absorption peaks in this region generally result from hydrogen vibrations.
- $\quad \mathrm{O}-\mathrm{H}$ and $\mathrm{N}-\mathrm{H}$ stretching vibration frequency absorptions are seen at $3700-3000 \mathrm{~cm}^{-1}$.

- The 1950-1550 $\mathrm{cm}^{-1}$ region: this region is called the carbonyl (C-O) double bond region.

- The 1500-700 $\mathrm{cm}^{-1}$ region: This region is called the fingerprint region. Most of the single bond absorption peaks are collected in this region. Esters ( $\mathrm{C}-\mathrm{O}-\mathrm{C})$ ethers (R-O-R) inorganic phosphates, inorganic sulfates, inorganic carbonates, and inorganic nitrates are observed in this region (Figure 1) [4].

IR (infrared spectroscopy) has recently become one of the molecular methods used in invertebrate animals for taxonomic purposes. This study is the first to identify functional groups in water mite species using IR. The infrared technique was used for the first time in Acaridae in 1989 by Leal et al. In this study, Leal and colleagues isolated rosefuran and perylene derivatives from Tyrophagus neiswanderi (Acariformes, Acaridae) species. The study described these natural compounds using $\mathrm{IR}$ and other spectroscopic techniques and compared them with synthetic ones [17].

Another study by Leal et al. (1989) isolated a novel monoterpene 2(E)-(4-methyl-3-pentenyl) butanediol ( $\alpha$-acari dial) from another Acari species, Tyrophagus pernicious, and determined the structure of this compound by spectroscopic methods (GS-FTIR, MS). Subsequently, a series of reactions on the part of this compound was carried out to obtain the $E$ and $Z$ isomers of this $\alpha$-acari dial compound. The study also compared the spectroscopic results of these natural monoterpene derivatives with that of synthetic ones [17]. A similar study by Hiraoka and colleagues (2001) obtained a mixture of two monoterpenes from Histiogaster sp. A096

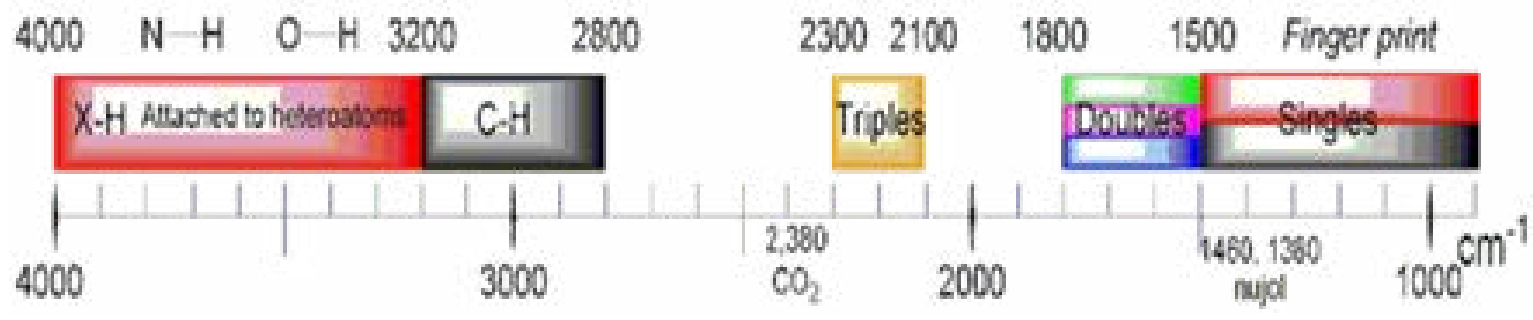

Figure 1. Functional group regions [4].

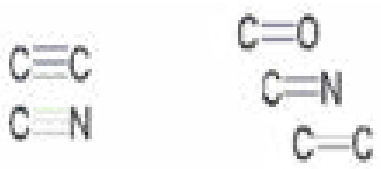


(Acari: Acaridae). They then elucidated their structure by GC/MS, GC/FTIR, UV and $1 \mathrm{H}$ NMR spectroscopy ((2E, $4 \mathrm{E})$ - and (2Z, 4E)-3,7-dimethyl-2,4,6-octatrienals) [18]. In a study conducted by Sato et al. (1993) researchers extracted a new salicylaldehyde derivative with a yield of $37 \%$ by extracting Dermatophagoides pteronyssinus, a type of mite, with hexane [19]. In another study, a new monoterpene lactone was obtained from Tyrophagus putrescentiae, a type of mold fungus by Morino and coworkers (1997). The researchers noted the chemical name of this lactone as (E)-2-(4'methyl-3'-pentenylidene)-4-butanol and assigned it the $\beta$-acarolide trivial name [20]. There is no information in the literature about the use of this method in relation to water mites. In the present study, the similarities or differences between species belonging to different families were evaluated using a systematic approach.

\section{MATERIALS and METHODS}

The water mites used in the study were collected from Karamık Lake (Afyonkarahisar-Turkey) from May-August 2015. Samples were identified in the laboratory under a microscope. The samples were washed with pure water and dried in sterile petri dishes at room temperature;
$100 \mathrm{mg}$ of anhydrous $\mathrm{KBr}$ (potassium bromide) was added to roughly $5 \mathrm{mg}$ of water mite species (Hydrodroma despiciens, Eylais infundibulifera, Hydryphantes flexiosus, Georgella helvatica, Hygrobates nigromacutlatus, Hydryphantes thoni, Torrenticola bevirostris) by weighing each species with a precision scale. The mixture of water mites and potassium bromide was placed into a mortar and thoroughly crushed for homogenization. This mixture was pressed into thin transparent discs and then analyzed by FTIR (Perkin Elmer Spectrum BX). The results of the analysis were graphically evaluated.

\section{RESULTS}

When the results obtained from samples of seven water mite species were examined, four functional groups in the spectrum were observed. These functional groups were: (1) functional group $(\mathrm{OH}, \mathrm{NH})$ in the range of $3600-3200 \mathrm{~cm}^{-1}$; (2) functional group $(\mathrm{C}-\mathrm{H})$ in the range of $2900-2850 \mathrm{~cm}^{-1}$; (3) functional group (C-C, C=O, C=N) in the range of $1780-1650 \mathrm{~cm}^{-1}$; (4) functional group (C$\mathrm{O}, \mathrm{C}-\mathrm{N}, \mathrm{C}-\mathrm{S}$ ) in the range of $1200-400 \mathrm{~cm}^{-1}$ (Figure 1). All of these functional groups were observed in all species.

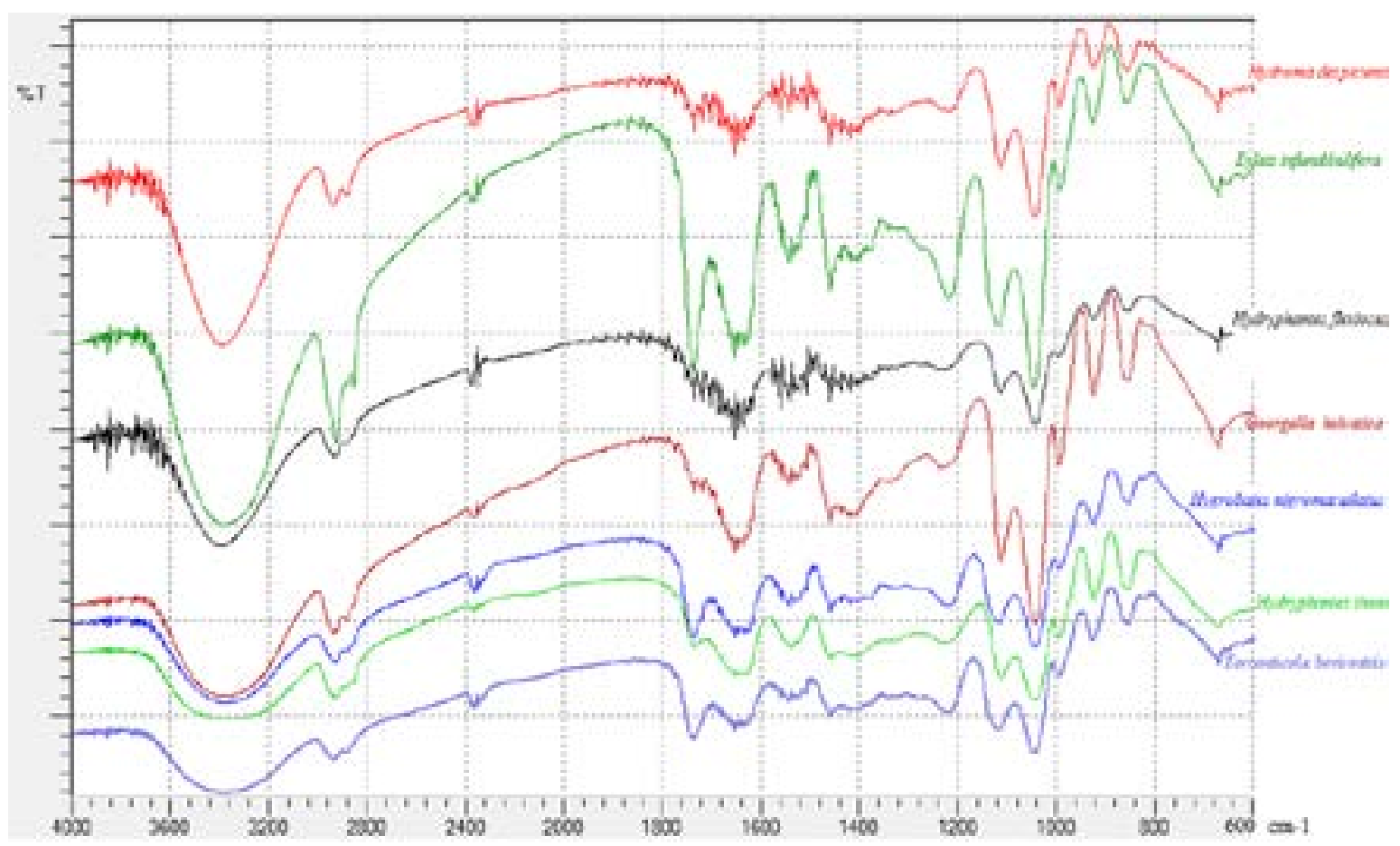

Figure 2. FTIR analysis of water mites species Hydrodroma despiciens (1), Eylais infundibulifera (2), Hydryphantes flexiosus (3), Georgella helvatica (4), Hygrobates nigromacutlatus (5), Hydryphantes thoni (6) and Torrenticola bevirostris (7). 
The first functional group is the $\mathrm{OH}$ and $\mathrm{NH}$ range. It is observed that the similarity rate among the six species studied for this region is very high. This result is also expected. Because it is the carbohydrates and proteins that make up the structure in living things. $\mathrm{OH}$, group is the basis of carbohydrates and $\mathrm{NH}$ group is the basis of proteins. When the $\% \mathrm{~T}$ values are examined; bands in the range of $3600-3200 \mathrm{~cm}^{-1}$ it is seen that Eylais infundibulifera and Hydrodroma despcidiens are more similar to each other. On the other hand, it is understood that Georgella helvatica, Hygrobates nigromacutlatus, Hydryphantes thoni, and Torrenticola bevirostris are more similar to each other in these functional groups in the same region. This situation does not support the taxonomic order based on structural features at the genus and family level [21-22].

The second functional group is the stretching vibration region of aliphatic and aromatic $\mathrm{C}-\mathrm{H}$ bonds. This band in the range of $2900-2850 \mathrm{~cm}^{-1}$ is observed in almost all organic compounds. In the studied species, the graphical analysis values of this region were observed very close to each other.

The second functional group region is the double bond at $\mathrm{C}-\mathrm{C}, \mathrm{C}-\mathrm{O}$ or $\mathrm{C}-\mathrm{N}$ in the range of $1780-1650 \mathrm{~cm}^{-1}$. These functional groups are found in the amino acids that form the basis of proteins. Therefore, it can be said that the third functional group belongs to proteins. When the studied species are considered in terms of these groups, it is seen that at least one of these functional groups is found in all. Although the similarity between species is very high in this region, Eylais infundibulifera is different from others in this range. It is known that this species has a different morphological structure in the family of Eylaidae than all other species of Eylais. Because this species of chitinization is different from the others [21, $24,25]$. Though there is more chitinization in the species of Torrenticola brevirostris, the same difference is not seen in the graph. The fourth functional group is in the region of $1200-400 \mathrm{~cm}^{-1}$. This region is also known as the fingerprint region. The frequencies of $\mathrm{C}-\mathrm{O}, \mathrm{C}-\mathrm{N}$ functional groups are in this range. These bonds form the basis of both carbohydrates and proteins. Within this functional group, the frequency of Hydryphantes flexus differs. But it seems that the others are more similar to each other in terms of their general qualities.

\section{DISCUSSION}

When all these data are examined in whole, it seems that it is not possible to use the results in a systematic comparison in different species of water mites. But it can be considered that this method may be useful for future studies in terms of determining the chemical structures of the species and determining the compositions of the basic organic compounds (carbohydrate, protein, lipid, etc.).

When comparing this study with previous studies, the difference is that previous studies have been directed toward the identification of individual alkaloids. In these previous studies, the structures of alkaloid derivatives have been elucidated and separated into their isomers by different reactions. Furthermore, new compounds were obtained from these and trivial names were given and the results were compared with synthetic market products. The purpose of this study is; Analyzing the whole as a living thing and making a comparison between species of the same group in terms of chemical structures. Another difference is; Previous studies were done with CS-FTIR technique, solid phase FT IR technique was used in this study. When these two techniques are compared, the samples to be analyzed are taken as gas in the CS-FTIR method, while the samples are taken as potassium bromide discs in the solid FTIR method. However, there is no difference in terms of the obtained spectrum values.

\section{CONCLUSION}

In this study water mites (Acari, Hydrachnidia) species (Hydrodroma despiciens, Eylais infundibulifera, Hydryphantes flexiosus, Georgella helvatica, Hygrobates nigromacutlatus, Hydryphantes thoni, and Torrenticola bevirostris) were used. The chemical analyses of these species were carried out by the Fourier transform infrared spectrophotometer (FTIR). The results of the analysis for all species were evaluated graphically and four spectral regions belonging to these species have been identified. The vibrational frequencies of each species studied were determined. When evaluating the results of FTIR analysis, the range of the spectrum of these species was shown to be similar to each other (Figure 2). 


\section{Acknowledgments}

This study was supported by a project of the Afyon Kocatepe University Research Foundation, Project No. BAP.16.FENED.02, 2017.

\section{References}

1. A. Di Sabatino, H. Smit, R. Gerecke, T. Goldschmidt, N Matsumoto, B. Cicolani, Global diversity of water mites (Acari, Hydrachnidia; Arachnida) in freshwater, Hydrobiol., 595 (2008) 303-315.

2. I.M. Smit, D.R. Cook, Water mites. In J.H. Thorp and A.P. Covich, eds., Ecology and classification of North American freshwater invertebrates, Academic, San Diego, CA, USA. (1991) 523-592.

3. E. Meyer. Der Entwick lungs zyklusvon Hydrodroma despiciens (O.F. Müller, 1776) (Acari, Hydrodromidae), Arch. Hydrobiol. Suppl., 66 (1985) 321-453.

4. D.A. Skoog, D.M. West, Principles of instrumental analysis (Vol. 158). Philadelphia: Saunders College pp.

5. H. Smit, 2015. The water mite family Hygrobatidae Koch in Australia. The genera Aspidiobatella Cook, Australorivacarus Viets, Gondwanabates Imamura and Rhynchaustrobates Cook (Acari: Hydrachnidia), Zootaxa., 4033 (1980) 567-583.

6. P.V.Tuzovskij, K.A, Semenchenko, Morphology and taxonomy of deutonymphs of the genus Unionicola Haldeman, 1842 (Acari, Hydrachnidia, Unionicolidae) in Russia, Zootaxa., 69 (2015) 3994.

7. Y.Ö. Boyaci, P.Gülle, New records of the water mite family Hydryphantidae (Acari: Hydrachnidia) from Turkey, with the description of a new species. Syst. Appl. Acarol., 19 (2014) 160-165.

8. F. Aşçı, G.U. Akkuş, I. Yaman, Determination of the ecological impact levels on Hydrodroma despiciens (Müller 1776) (Acari, Hydrachnidia) which is a common water mite in terms of heavy metal applications, Pak. J. Zool., 48 (2016) 345-348.

9. F. Aş̧̧ı, M. Bahadır, G.U. Akkuş, Study on the Impact of Elements in Water on the Diversity of Water Mites (Acari, Hydrachnidia) Species, Adv. Biosci. Biotechnol., 6 (2015) 259-264.

10. S.T. Onrat, F. Aş̧̧ı, M. Özkan, A cytogenetic study of Hydrodroma despiciens (Müller, 1776) (Acari, Hydrachnellae, Hydrodromidae), Genet. Mol. Res., 5 (2006) 342-349.

11. P. Martin, M. Koester, L. Schynawa, R. Gergs, First detection of prey DNA in Hygrobates fluviatilis (Hydrachnidia, Acari): A new approach for determining predator-prey relationships in water mites, Exp. Appl. Acarol., 67 (2015) 373-380.

12. B.A. Dorda, A.G. Valdecasas, Traditional water mite fixatives and their compatibility with later DNA studies, Exp. Appl. Acarol., 34 (2002) 59-65.
13. A.J. Bohonak, B.P. Smith, M. Thornton, Distributional, morphological and genetic consequences of dispersal for temporary pond water mites, Freshw Biol., 49 (2004) 170180

14. B.R. Ernsting, D.D.Edwards, M.F. Vidrine, K.S. Myers, C.M. Harmon, Phylogenetic relationships among species of the Subgenus parasitatax (Acari: Unionicolidae: Unionicola) based on DNA sequence of the mitochondrial cytochrome oxidase I gene, Int. J. Acarol., 32 (2006) 195-202.

15. M. Więcek, P. Martin, A. Lipinski, Water mites as potential long-term bioindicators in formerly drained and rewetted raised bogs, Ecol. Indic., 34 (2013) 332-335.

16. S.W. Sharpe, T.J. Johnson, R.L. Sams, P.M. Chu, G.C. Rhoderick, P.A. Johnson, Gas-phase databases for quantitative infrared spectroscopy, Appl. Spectrosc., 58 (2004) 1452-1461.

17. J. Chen, B. Gu, E.J. LeBoeuf, H. Pan, S. Dai, Spectroscopic characterization of the structural and functional properties of natural organic matter fractions, Chemosphere., 48 (2002) 59-68.

18. W.S. Leal, Y. Kuwahara, Y. Nakano, H. Nakao, T. Suzuki, 2 (E)-(4-Mcthyl-3-pentenyl)- butenedial, $\alpha$-Acaridial, a Novel Monoterpene from the Acarid Mite Tyrophagus perniciosus (Acarina, Acaridae), Agric. Biol. Chem., 53 (1989) 1193-1196.

19. M. Sato, Y. Kuwahara, S. Matsuyama, T. Suzuki, 2-Formyl3-hydroxybenzyl formate (rhizoglyphinyl formate), a novel salicylaldehyde analog from the house dust mite Dermatophagoides pteronyssinus [Astigmata, Pyroglyphidae], Biosci. Biotech. Biochem., 57 (1993) 12991301.

20. H. Hiraoka, N. Mori, R. Nishida, Y. Kuwahara, (4E)Dehydrocitrals $[(2 \mathrm{E}, 4 \mathrm{E})$-and $(2 \mathrm{Z}, 4 \mathrm{E})-3$, 7-dimethyl-2, 4, 6-octatrienals] from Acarid Mite Histiogaster sp. A096 (Acari: Acaridae), Biosci. Biotechnol. Biochem., 65 (2001) 2749-2754.

21. A. Morino, Y. Kuwahara, S. Matsuyama, T. Suzuki, (E) 2-(4'-Methyl-3'-pentenylidene)-4-butanolide, Named $\beta$-Acariolide: A New Monoterpene Lactone from the Mold Mite, Tyrophagus putrescentiae (Acarina: Acaridae), Biosci. Biotechnol. Biochem., 61 (1997) 1906-1908.

22. M. Özkan, Doğu Anadolu Su Akarları (Acari, Hydrachnellae) Üzerine Sistematik Araştırmalar-II. Atatürk Üniversitesi, Fen Fak. Derg. 1 (1982) 145-163.

23. C. Bader, H. Sepasgozarian, Wassermilben (Acari, Prostigmata) aus dem Iran - 5. Mitteilung. Hydrovolzia persica nov. spec. Acarologia, 21 (1979) 70-83.

24. K. Viets, VII: Wassermilben oder Hydracarina (Hydrachnellae und Halacaridae). Die Tierwelt Deutschlands und der angrenzenden Meeresteile nach ihren Merkmalen und nach ihrer Lebensweise (TI. 31, 32) Show all parts in this series, 1936.

25. L. Szalay, Víziatkák Hydracarina fauna Hungariae, Akadémiai Kiadó, Budapest, 380, (1964) Google Scholar. 